\title{
ZIC2 Gene
}

National Cancer Institute

\section{Source}

National Cancer Institute. ZIC2 Gene. NCI Thesaurus. Code C75537.

This gene plays a role in transcription and neuronal development. 